\title{
Patience, Suffering, and Tolerance: The Experience of Defeat and Exile among the Jesuits of Ethiopia $\left(163^{2}-59\right)$
}

\author{
Leonardo Cohen \\ Department of Middle East Studies, Ben-Gurion University of the Negev, \\ Be'er Sheva, Israel \\ leonardo@post.bgu.ac.il
}

\begin{abstract}
This article explores the last letters written by the Catholic patriarch of Ethiopia in exile Afonso Mendes, which illustrate that, in the face of defeat, Mendes has chosen to write the history of martyrdom, the sacrifice, and shedding of blood for the sake of faith. A group requires a sense of connection through a temporary axis. Mendes's choice in these last years corresponds to the will of generating cohesion in space and continuity in time in a group that has confronted rupture, disillusionment, and deterioration. Mendes might have attempted to establish a framework that would allow him to alleviate the tension caused by the clash between the original aspirations and the flawed fulfillment of the objective. Therefore, the redaction of the processes of martyrdom and the creation of a calendar allows the transition into a place where a harmonious relationship between the past and the present is generated.
\end{abstract}

\section{Keywords}

Afonso Mendes - Ethiopia - Jesuit missionaries - history of martyrdom - exile suffering and patience

By 1625, it seemed that Catholicism had won over Ethiopia. The Catholic Church - and the Society of Jesus in particular — had made an enormous effort to fulfill the Ignatian dream of reconciling the Church of Ethiopia with the Catholic Church under the tutelage of the pope in Rome. The newly appointed 
Catholic patriarch of Ethiopia, Portuguese Jesuit Afonso Mendes (1579-1659), was welcomed by Emperor Susənyos (1572-1632; r.1607-32) with great honors. A momentous ceremony took place on February 11, 1626, seemingly bringing to an end a history of heresies and opening the gate to a future in which the beliefs of the Catholic Church would be confirmed by the leading players of the Ethiopian empire. The Jesuit Manuel de Almeida (1580-1646) described the dramatic event as follows:

This most sacred, religious, and solemn act was performed [on] Wednesday February 11 of the year 1626. It can duly be said that there is no happier day that Ethiopia deems fitter to celebrate with demonstrations of true joy on an annual basis, for on this day the luminous light of the true and holy Catholic faith dawned, on this day the darkness of Egypt was undone and extinguished; drowned in the Red Sea were the errors and heresies of Eutychian and Dioscorus; broken was the vile yoke of the most ignorant abunas and patriarchs of Alexandria; elevated was Ethiopia with the dignity of God's daughter and she can now sing with Moses and his sister Mary: In exitu Israel de Egypto, domus Iacob de populo barbaro, facta est Iudaea sanctificatio eius, ${ }^{1}$ etc.

For this solemn act, the imperial hall was decked out in its finest. All the empire's luminaries were present, from princes and the emperor's brothers, to viceroys, captains, azages, ${ }^{2}$ and ombares $^{3}$ — who comprised the entire tribunal

1 I want to thank Marianela Santoveña and Avi Aronsky for their collaboration in translating some of the sources. I would especially like to thank my dear brother Moises Cohen who, based on his training as a psychologist, provided significant suggestions for the preparation of this article. I dedicate this text to him. "When Israel went out from Egypt, the house of Jacob from a people of strange speech, Judah became God's sanctuary” (Psalm 114:1-2).

2 Literally "commander," azzaž (or azages) was a common term for civil administrators. According to Sevir Chernetsov, "being men of profound ecclesiastical learning, they were dressed as ecclesiastics as well, in white gown and white turban, and had a small staff of subordinates, usually literate clerics. Apparently in the fifteenth and sixteenth centuries these were, with the exception of the royal clergy, the only civil courtiers whose services Ethiopian kings needed." Sevir B. Chernetsov, "Azzaž," in Encyclopaedia Aethiopica, ed. Siegbert Uhlig, 5 vols. (Wiesbaden: Harrassowitz Verlag, 2003), 1:422.

3 The plural form of the Amharic term wämbär, ombares literally means "chair" or "seat." The term commonly refers to top-ranking judges that accompanied the emperor or regional governors on the legal circuit. Although the representatives of the executive usually rendered the verdicts, these judges occasionally decided cases on their own. See Steven Kaplan, "Wämbär," in Encyclopaedia Aethiopica, 4:1125-26. 
and court of justice-as well as däbtäras ${ }^{4}$ and the most austere monks who had already received the Holy Roman faith. Beside the throne-the imperial bed-two stately chairs were mounted. The one to the right was occupied by the emperor, while the patriarch sat in the one to the left, cloaked and pontifical with diadem and ceremonial cape. When silence prevailed, the patriarch commenced a long discourse - a fitting homily for this eventful day. He turned to the words that Christ our Lord said unto Saint Peter: Tu es Petrus et super hanc petram aedificabo ecclesiam meam. ${ }^{5}$ By virtue of the great solemnity of this occasion and the speakers' evocation of canonical passages, the authority of saints, and other venerated stories that duly attested to the supremacy of the Latin rite, I would be remiss if I were to withhold the backdrop behind this episode. ${ }^{6}$

The setting and choreography of this event articulated the glory of a victorious Catholicism, a story that appeared to be one of irreversible triumph. The above-cited passage was just the beginning of a speech prepared by Patriarch Mendes for this historical moment. I have dealt with the content of the patriarch's sermon elsewhere. ${ }^{7}$ A mere seven years after the extravaganza, however, the Jesuits found themselves en route to Goa, banished from Ethiopia by the successor of Susənyos, Emperor Fasilädäs (1603-67; r.1632-67). Other Jesuits, along with part of the Ethiopian Catholic community, remained in Ethiopia and suffered harassment, humiliation, and martyrdom. Fasilädäs, who rose to power in 1632, had renounced his father's course and restored the Orthodox Ethiopian Church as the pillar of local religious identity.

This categorical failure prompted a deep sense of disappointment among the missionaries of the Society of Jesus-contemporary scholars of religion have described it as "the collapse of an illusion." project in Ethiopia produced pain on multiple levels: emotional and physical trauma for those who suffered precarity and persecution in Ethiopia as well as

4 The däbtäras may be described as lay ecclesiastics. The däbtäras "occupy an intermediate position between the clergy and the laymen. They are not ordained, but no service can be held without them." Steven Kaplan, "Däbtära," in Encyclopaedia Aethiopica, 2:53-54.

5 "You are Peter, and on this rock I will build my church" (Matthew 16:18).

6 Camillo Beccari, Rerum Aethiopicarum scriptores occidentales inediti a saeculo XVI ad XIX, 15 vols. (Rome: C. De Luigi, 1903-17), 6:481-82.

7 For a detailed description of the content and performance of this ceremony, see Leonardo Cohen, "Shaking the Dust from the Feet': Ritual and Testimony among Jesuits and Ethiopian Catholics (Seventeenth Century)," in Narratives and Representations of Suffering, Failure, and Martyrdom: Early Modern Catholicism Confronting the Adversities of History, ed. Leonardo Cohen (Lisbon: CEHR-Universidade Católica Portuguesa, 2O2O), 203-15.

8 Carlos Domínguez Morano, El psicoanálisis freudiano de la religión: Análisis textual y comentario crítico (Seville: Ediciones Paulinas, 199o), 365. 
the humiliation of those who recrossed the sea, answering to the authorities in Goa. ${ }^{9}$ The present article aims to examine not only how the missionary leaders accounted for the Ethiopian failure, but also how such suffering was presented in their written testimonies.

\section{The Global Context of the Jesuit Defeat}

The Jesuits in Ethiopia relinquished the Ignatian dream of church reconciliation only after putting up an impressive fight. The exchange of letters during this period attests to the massive efforts made to recover what had been lost, even resorting to the support of Portuguese military reinforcements. Nonetheless, geopolitical reality proved overwhelming to Jesuit hopes.

In Ethiopia, Portuguese attempts to return to the coasts of the Red Sea were perceived with growing suspicion. Emperor Fasilädäs and his people sensed a link between the Catholic community and the interests of the Portuguese state. In the wake of the dramatic restoration of 1632 , a wave of xenophobic sentiment, aimed mainly at Roman Catholics, spread throughout Ethiopia. Fasilädäs's suspicion of Portuguese activities in India prompted Emeri van Donzel's apt question: was this perception what drove the Ethiopian emperor to send ambassadors to three different Muslim governments? ${ }^{10}$ In any case, Catholics in Ethiopia, associated by the natives with Portuguese culture and tradition, were considered allies of the enemy. ${ }^{11}$

Surviving letters are filled with the anguish of the Catholic community in Ethiopia in those years. A case in point is the following letter of Bernardo Nogueira (1603-53) - the priest who became the highest authority of the Catholic Church in Ethiopia, in the absence of the patriarch - to Mendes: "So I end by asking and beseeching you to provide us with the necessary succor, as befitting your pastoral and fatherly obligation to your children and flock, for we are at the end of our miseries."12 In Nogueira's view, the fratricidal war between Fasilädäs and his brother Gälawdewos (d.1648) hinged on the latter's

9 On the accusations directed at the Jesuits by the representatives of other religious orders, specifically concerning the failure in Ethiopia, see Leonardo Cohen, "Imprudentia maxima': Fray Manuel de Asunción y su crítica de la actuación de los jesuitas en Etiopía," Lusitania sacra 32 (2015): 81-104.

10 Emeri van Donzel, Foreign Relations of Ethiopia 1642-1700: Documents Relating to the Journeys of Khodja Murad (Leiden: Nederlands Historisch-Archeologisch Institute Istanbul, 1979), 2. See also Matteo Salvadore, "Muslim Partners, Catholic Foes: The Selective Isolation of Gondärine Ethiopia," Northeast African Studies 12 (2012): 61-66.

11 Andreu Martínez d'Alòs-Moner, Envoys of a Human God: The Jesuit Mission to Christian Ethiopia (1557-1632) (Leiden: Brill, 2015), 311-23.

12 Beccari, Rerum Aethiopicarum scriptores, 13:267, 322. 
loyalty to the Portuguese. ${ }^{13}$ In this vein, Nogueira wrote, "Every day the emperor sends spies to the strait and to Arabia to retrieve news of events. They all cried with one voice: the Portuguese are coming, and then they took counsel: let us kill them all."14 By 1649, the news from Ethiopia was catastrophic. Nobles and learned Catholics were martyred and the Portuguese in Maygoga ${ }^{15}$ had abandoned their faith. ${ }^{16}$

These were difficult decades for the Portuguese empire in the East. The growing number of Dutch and English attacks as well as the shortage or total lack of European reinforcements helps account for the disasters suffered by Portugal from 1630 on. Spain was at war worldwide and needed Portuguese money; it required resources to build, equip, and send ships loaded with armies and ammunition to places where the Portuguese and Spanish empires were being assailed: Brazil, Africa, and Asia. Since 1550, the enemies of the Portuguese had increased in both number and strength. ${ }^{17}$

Between 1640 and 1660, the government of Lisbon was forced to abandon Asia in order to salvage the main possessions of the empire: Brazil and its complementary African territories. Aware that they lacked the ability to defend all their territories, the Portuguese chose the most promising one, where white colonization had permanently spread and where commercial benefits could offset the declining revenues from the East. ${ }^{18}$ After the restoration in Portugal, the kingdom's foreign policy focused on making peace with the Netherlands and obtaining the military and diplomatic support of the enemies of Spain.

13 Beccari, Rerum Aethiopicarum scriptores, 13:284. Between 1645 and 1647, Torquato Parisiani wrote a comprehensive description of the "plot" while residing on the coast of the Red Sea. He asserted that Gälawdewos and his allies were so desperate in light of the perceived decadence of the Ethiopian state that they planned to depose Emperor Fasilädäs. On the other side, the Abunä Marqos denounced Gälawdewos to the emperor because of his fear of Catholicism. Anaïs Wion suggests that Nogueira and Parisiani both reported that Gälawdewos wanted to restore Catholicism because this was the only way they could interpret a rebellion against Fasilädäs. See Anaïs Wion, "Why Did King Fasilädäs Kill His Brother?: Sharing Power in the Royal Family in Mid-Seventeenth Century Ethiopia," Journal of Early Modern History: Contacts, Comparisons, Contracts 8 (2004): 259-93, here 267-68. Patriarch Afonso Mendes depicted Gälawdewos as a martyr, his severed head buried in the grave of his father, Emperor Susənyos. See Beccari, Rerum Aethiopicarum scriptores, 9:375.

14 Beccari, Rerum Aethiopicarum scriptores, 13:284.

15 Also known as May Qahq qəhä, this village is located in the region of Təgray, near Fəremonaone of the principal centers of Jesuit activity in Ethiopia.

16 Beccari, Rerum Aethiopicarum Scriptores, 13:322.

17 António H. de Oliveira Marques, History of Portugal (New York: Columbia University Press, 1976), 335-38.

18 De Oliveira Marques, History of Portugal, 338. See also Charles R. Boxer, The Portuguese Seaborne Empire 1415-1825 (London: Pelican Books, 1973), 108-29. 
However, an immediate peace with the Dutch implied that the latter would have to give up their aspirations in Asia and the Atlantic. Despite the skillful efforts of the restoration diplomats and their pledges of economic compensation, the United Provinces put off the signing of a peace treaty until 1661. In the 163os, most of Ceylon was occupied by the Dutch, who, from 1639 onwards, blocked Goa for several years. After the restoration, the disasters intensified and accelerated, as the government was obliged to organize resistance in the metropolis, and only reluctantly authorized reinforcements. Malacca capitulated to the Dutch in 1641 . A ten-year armistice (1641-51) temporarily halted Portugal's decline, but the treaty collapsed in 1651. Large numbers of forts and factories in India were surrendered in 1653, Colombo was captured by the Dutch in 1656 , while the rest of Ceylon fell two years later, followed by Crangagor and Cochin (1662). Bombay was finally ceded to the English in 1665. At the same time, Arabs, aided by the English and Dutch, expelled the Portuguese from Arabia and the Persian Gulf. ${ }^{19}$

News of the coup d'état in Lisbon, which transpired on December 1, 1640, reached Asia thanks to the warning ships that left the metropolis the following year. King João IV (1604-56; r.164O-56) was acclaimed by Viceroy Dom João de Silva Telo in Goa, but the Iberian contraction in Asia proved unstoppable, for the Portuguese Braganzas as well as the Spanish Habsburgs. In January 1641, Malacca fell into Dutch hands and, in August, it was the turn of Luanda, though the Portuguese would later recover the city. In 1685, Ceylon was surrendered to the Batavians, along with all its missions. Owing to this string of losses, it is not surprising that King João IV himself told the French ambassador that he was ready to leave India rather than sacrifice Brazil. In 1649, his war advisers, D. Fernando Mascarenhas (c.1610-51) and João Costa (1610-64), had suggested: "We should leave Asia in order to stay with Brazil, because as long as we are neighbors [of the Dutch] peace will never be safe and our spices are not so valuable and Asia, because of its distance and size, is more difficult and costly and less useful in terms of its conservation."20 While considering the correct order of priorities for Portugal, João IV was reminded by the Finance Council why Portugal should preserve those lands: "to propagate the Catholic faith, for the kingdom's reputation and of his prince, for the profits of commerce, and for the comfort of the poor nobility, who in that conquest alone have acquitted themselves with honor."21

19 Oliveira Marques, History of Portugal, 329.

20 Rafael Valladares, Castilla y Portugal en Asia (1580-1680): Declive imperial y adaptación (Leuven: Leuven University Press, 2001), 66.

21 Valladares, Castilla y Portugal en Asia, 73. 
If any institution was content with the new regime, in the metropolis and beyond, it was the Society of Jesus. As Rafael Valladares rightly points out, such enthusiasm must be seen as part of the general support the church of Portugal lent to the restoration, retaliating against the fiscal threat the Philippine regime had levelled against the church's considerable wealth. Still, some Jesuits across the sea foresaw that the situation in the missions would not necessarily improve: "It cannot be denied that in recent times of Castilian rule in Portugal," wrote a Portuguese Jesuit in 1647 , "the ministry of conversion was almost lost in those parts, but nothing less was expected of the government that convened the Council of Madrid at which an attempt was made to altogether abandon East India and its Christian populace, ceding it to Moors and heretics." The same priest lamented: "Now that the government is ours, the king's policy is not better directed, with the missions receiving so little support."22 In circumstances of war, the crown occasionally perceived the Jesuits as troublemakers. The revolt that broke out in India in 1653 among Christians who practiced the Malabar rite was blamed on the intransigence of Francisco García (1580-1659), the Jesuit bishop of Cranganore. At least this was the way things were perceived by the viceroy, Dom Vasco de Mascarenhas (c.1605-78), the Inquisition, and other orders (especially the Franciscans), who saw the conflict as an opportunity to attack the Society's missionary exclusivism. When King João IV came to the defense of the Jesuits, it was probably to prevent the inevitable: the intervention of the Holy See. ${ }^{23}$ Since Rome, under Spanish pressure, had not recognized the Braganza regime (and would not do so until 1669), sending a papal mediator to India would have been humiliating for the king. ${ }^{24}$ The revolt ended with García's death in 1659, allowing a compromise of pacification. But the wounds the war had opened between the orders and the relevant institutions further weakened Portuguese resistance to the Dutch offensive: Cranganore fell in 1662 and Cochin in 1663. This disaster did not find its origin in the revolt of the Malabars but helped accelerate the former. Without a doubt, the Jesuits followed their own interests rather than those of the crown or even the pope..$^{25}$

From 1640 on, tensions mounted between the Portuguese crown and the other centers of power in the East. Between 1640 and 1670, the Luso-Castilian

\footnotetext{
22 Quoted in Valladares, Castilla y Portugal en Asia, 73.

23 Joseph Thekedathu, The Troubled Days of Francisco García, S.J., Bishop of Cranganore, 1641-1659 (Rome: Università Gregoriana Press, 1972).

24 See Fortunato de Almeida, História da Igreja em Portugal, nova edição dirigida y preparada por Damião Peres, 4 vols. (Porto: Livraria Civilização Editora, 1968), 2:335-42. 
contraction in Asia intensified, leaving both crowns deeply weakened. The restoration did not respond to the interests of the Portuguese overseas and even less so at home. Instead, the war catered to the privileged groups that orchestrated and directed it. After the fury of the war and with the monarchy more vulnerable than ever, the cessation of fighting allowed for the resumption of commerce and missionary work. The empire had, after all, survived, and its remaining territories were exactly as their inhabitants wished: autonomous, distant and, in their official poverty, incredibly rich. Even so, all the parties recognized that the mythical state of India would never return to the brilliance of yesteryear. ${ }^{26}$

The Catholic patriarch testified that, from 1641 to 1645 , none of the ships departing from Dio to Suakin reached the coasts of the Arabian peninsula. In 1642, the Jesuit António de Andrade (1610-69) traveled aboard one of these ships at the behest of Mendes. Andrade was born in Ethiopia and of Portuguese origin. Finding entry to Ethiopia impossible, he followed the advice of a Capuchin friar who suggested that he travel to Rome. ${ }^{27}$ In July 1646, Antonio de Petrapagana confirmed from Suakin that entry for the Portuguese was blocked by the joint forces of the Turkish pasha and Emperor Fasilädäs. ${ }^{28}$

In early 1645 , the viceroy of India wrote to João IV, requesting that he take into consideration the suggestion of the Catholic patriarch to take the ports of Suakin and Massawa, at a time when it seemed to him favorable to do so. ${ }^{29}$ However, on May 5 of the same year, the Sacra Congregazione de Propaganda Fide demurred, citing the difficulties involved in allowing Catholic entrance to the Red Sea. ${ }^{30}$

In light of these events, Mendes's drive to return the Jesuits to the Red Sea, which began in 1633 and continued until 1650, was rather remarkable. In a letter to the superior general of the order dated to November of the latter year, Mendes detailed the annual attempts to enter Ethiopia through the coasts of the Red Sea, sending emissaries incognito to glean information and re-establish contact with the Portuguese living in Ethiopia. ${ }^{31}$ In December 1646, he inquired from Goa as to whether permission had been obtained from the pasha to send two priests in Massawa or Suakin. The provincial of the Society

26 Valladares, Castilla y Portugal en Asia, 90-91.

27 Beccari, Rerum Aethiopicarum scriptores, 13:251-53, 259.

28 Beccari, Rerum Aethiopicarum scriptores, 13:261.

29 Beccari, Rerum Aethiopicarum scriptores, 13:248-49.

30 Beccari, Rerum Aethiopicarum scriptores, 13:249.

31 Beccari, Rerum Aethiopicarum scriptores, 13:362-63. 
of Jesus named Francisco Ferreira, who had been rector of the College of São Paulo and the priest Antonio Cesqui to form a search delegation. For various logistical reasons, neither made the trip. In his epistle, Mendes thanked God for this turn of events, reflecting on the difficulties that had arisen. ${ }^{32}$

From 1643 on, the irrevocable nature of their loss became apparent to the Jesuits. In a letter to King João IV, Mendes again solicited the armed intervention of the Portuguese empire to liberate the Turkish-held ports of Massawa and Suakin. As a corollary to the missive about the dire straits of the Catholics in Ethiopia, Mendes requested that the king reassert Portuguese power in the Red Sea. "May our Lord grant respite from arms in Castile and Holland," he wrote, "as well as fortitude to our lord and king, João IV, to lift us from ruin, as did his uncle Dom João III, of glorious memory."33 From his years of experience in Ethiopia and from the information he had gathered, the Catholic patriarch concluded that "Ethiopia can only receive remedy from God through a miracle or from the Portuguese army [...]. For this, four ships and some eighty or more Portuguese men to hold the seized possessions would suffice."34

In January 1651, the king of Portugal instructed the viceroy of India to come to the aid of the Catholic patriarch. The viceroy was to send four vessels with eighty Portuguese soldiers to the Red Sea to take the fortress at Massawa; the hope was to intimidate the emperor of Ethiopia and incite a Catholic uprising. ${ }^{35}$ December saw the viceroy expressing serious misgivings regarding the effect of the action on the emperor of Ethiopia: eighty soldiers was deemed an insufficient number for the job, and the kingdom of Ethiopia lay inland, far from the Turkish-held port of Massawa. ${ }^{36}$

It seems that the response of the viceroy was the final nail in the coffin of the project that Mendes had advanced for fifteen years. The correspondence of this period does not document any attempt by Mendes to persuade secular authorities to initiate the program to recover Massawa and Suakin. From 1654 onwards, Mendes's correspondence bears witness to a decline in these efforts. In fact, he devoted the last years of his life to collecting material that would allow him to glorify the mission in Ethiopia, exalting the martyrdom of those who sacrificed their lives to build a Catholic Ethiopia:

\footnotetext{
32 Beccari, Rerum Aethiopicarum scriptores, 13:274-76.

33 Beccari, Rerum Aethiopicarum scriptores, 13:308.

34 Beccari, Rerum Aethiopicarum scriptores, 13:308-9.

35 Beccari, Rerum Aethiopicarum scriptores, 13:376.

36 Beccari, Rerum Aethiopicarum scriptores, 13:383.
} 
For one year and a half I have been extremely occupied with the processes of the blessed martyrs of Ethiopia. Some say this is the cause of my ailment. May God grant me health to conclude the processes, for if I were to die, they would remain imperfect. ${ }^{37}$

As noted by Ines Županov, the chronic shortage of staff that the Jesuits experienced in the East contributed to the configuration of this new narrative of martyrdom. The letters from Asia reiterated two statements that might otherwise appear unrelated. The first was of a mystical nature, namely the desire to suffer and die for Christ. The second was practical — the lack of Jesuit personnel in the mission. ${ }^{38}$ Exiled from Ethiopia, the Jesuits appealed to Ignatian terminology in order to grant coherence to sacrifice, pain, and martyrdom.

\section{Mourning and Collective Identity}

The Jesuit protagonists of this impending defeat also struggled through their writings to vindicate the order, to dignify the suffering of those who were unable to achieve their life-long goal, and to exalt martyrdom. In such circumstances, pain seems to have been a tool for forging interpersonal communion. The key to personal and collective mourning in the face of defeat and to enduring through grief relates to the Catholic tradition, especially its attempt to reconcile God's wisdom with human misery. ${ }^{39}$ Such a perception is even more explicit in the work of the founder of the Society of Jesus, Ignatius of Loyola (c.1491-1556). Ignatian literature clearly refers to hardship that is imposed, not sought; suffering caused by the loss of honor, by injury, humiliation, or failure;

37 Beccari, Rerum Aethiopicarum scriptores, 13:387-88.

38 Ines G. Županov, Missionary Tropics: The Catholic Frontier in India (16th-17th centuries) (Ann Arbor: The University of Michigan Press, 2008), 149.

39 Leszek Kołakowski synthetizes this idea as follows: "This attempt to reconcile God's wisdom with human misery is especially characteristic of all those currents within Christianityfrom Eriugena to Teilhard de Chardin - succumbed to the temptation of pantheistic belief in the total absorption, at the end of time, of whatever the history of the world has produced. From this standpoint evil is not ultimately evil at all: we only think of it as such because the complete history of salvation is beyond our reach, because we absolutize certain fragments of it without realizing that in the divine plan they serve the cause of good. Thus, the question of evil is not much solved but cancelled, since all the things we imagine to be evil are merely bricks for building a future perfection, and nothing is going to be wasted in the process." Leszek Kołakowski, Religion... If There Is No God (Oxford: Oxford University Press, 1982), 35. 
suffering caused by difficulties, weariness, and apostolic frustration. Unwished for by all, these travails are liable to throw life into disarray. ${ }^{40}$

Along these lines, we might say that the Jesuits in Ethiopia resorted to Ignatian terminology and Christian paradigms for the sake of defining the grief engendered by such disappointment: God proactively causes or allows this sort of hardship for some good. The challenge lies in enduring through this setbacks, while preventing them from derailing the life of an individual or the identity of a group or community.

Catholics who stayed in Ethiopia were punished by the local political and ecclesiastical authorities in different ways. ${ }^{41}$ While the ethos of martyrdom is a permanent fixture of the missionaries' work - as it is throughout the history of Christianity - martyrdom became the cornerstone of fidelity to Jesuit priests and Catholicism in general after the expulsion of Mendes and his followers. Those who achieved the greatest Catholic dignity are those who, by the Jesuits' own accounts, were willing to sacrifice their life rather than renounce their faith.

The sixteenth century witnessed a shift in the motif of martyrdom. As Brad S. Gregory informs us, martyrs were not needed as paragons of self-sacrifice in the late Middle Ages. Imitating their deaths lacked relevance in the absence of active enemies of the Christian faith. The situation changed, however, during the sixteenth and seventeenth centuries. In a world burdened with corporal and spiritual afflictions, Christians was desperate for the powers that God had granted His heavenly friends. ${ }^{42}$ The disastrous experience of the Society in Japan and the subsequent exaltation of Jesuit martyrdom may have also reinforced suffering as the fundamental path of Catholic life in Ethiopia. ${ }^{43}$ Within Ethiopia and beyond, the Catholic narrative highlighted this period as one of martyrdom. Manuel de Almeida (1578-1646), who during these years completed his History of Ethiopia in exile, ${ }^{44}$ titled one chapter of this work "Book

40 José Antonio García Rodríguez, "Dolor," in Diccionario de espiritualidad ignaciana, ed. José García de Castro et al., 2 vols. (Madrid: Mensajero-Sal Terrae, 2007), 1:659.

41 Martínez d'Alòs-Moner, Envoys of a Human God, 320-23.

42 Brad S. Gregory, Salvation at Stake: Christian Martyrdom in Early Modern Europe (Cambridge, MA: Harvard University Press, 1999), 34.

43 De Almeida links the return of the Ethiopians to their ancient heresies to a list of failures of the Catholic Church in the world, including the Japanese case. See Beccari, Rerum Aethiopicarum scriptores, 7:133. See also George Elison, Deus Destroyed: The Image of Christianity in Early Modern Japan (Cambridge, MA: Council on East Asian Studies, Harvard University, 1988).

44 Manuel de Almeida finished his Historia de Ethiopiaa Alta ou Abassia in Goa sometime between 1643 and 1645 . The work was edited by Beccari, Rerum Aethiopicarum scriptores, vols. 5-6. See also Michael Kleiner, "Almeida, Manoel de," in Encyclopaedia Aethiopica, 1:209. 
10 of the history of Ethiopia, telling how after the undoing of the holy faith in Ethiopia, many suffered grievous work for her sake, even giving up their life to achieve the glorious crown of martyrdom." 45 On the narrative level, the triumphalism of Catholic authors gave way to a vision of exalted suffering and martyrdom. In June 1646, the governor of the Catholic Church in Ethiopia, Bernardo Nogueira (1605-53), counted forty-five Catholic martyrs in Ethiopia since the expulsion of the Jesuits. ${ }^{46}$ The recurring stories of martyrdom along the Horn of Africa exemplify this trend of underscoring the charges against and death of Catholics who spilt their blood for the "true" faith. Once again, these cases attest to the link between Portuguese identity and Catholicism. At the court of the Tigrayan governor, the following question was put to three Catholics who were made to stand trial: "Why are you of the Portuguese faith?" In response, Däbtära Zä Śəllase posed two questions of his own: "What is it that you call the Portuguese faith? Why do you refuse to call it the holy and true faith?"47

For many believers, being Catholic meant not only to live as a Catholic but to die as one. Those who were willing to sacrifice their lives for their faith were most revered in the Jesuits' testimonies. The writings of the Jesuits who left for Goa after the expulsion from the Horn of Africa echo with the reverence for meeting trouble with discipline. The patriarch himself hoped for a martyr's death. In a letter to the superior provincial of Portugal, he stated that "it will be a great grief if death befell me in Goa: let the Lord command it to be in Ethiopia, and when it is not hung from a tree like Bishop Dom Apolinar, ${ }^{48}$ be thrown on a beach like the holy Father Francisco Xavier." ${ }^{29}$ For his part, Bernardo Nogueira situated his travails squarely within the history of the church. "The bad experiences we have to endure," he wrote to Patriarch Afonso Mendes from Ethiopia,

the cruel persecution suffered by your saintly wife, have never before been seen by the world, even in times of Constantius or Valens Arrius or of Zeno or Anastasius Eutychian. Many are the tribulations endured by the righteous; then, what will we, the righteous of the supreme God, do?

\footnotetext{
45 Beccari, Rerum Aethiopicarum scriptores, 7:197-477.

46 Beccari, Rerum Aethiopicarum scriptores, 13:265.

47 Beccari, Rerum Aethiopicarum scriptores, 7:464.

48 After the banishment of the Jesuits from Ethiopia, the bishop Apolinar de Almeida clandestinely remained in Ethiopia for some time. Following a series of extreme difficulties and banishments, he was lynched together with his companions Jacinto Francisco and Francisco Rodrigues.

49 Beccari, Rerum Aethiopicarum scriptores, 13:183.
} 
Blessed be He for all. More reasons do we have to be grateful to Him than to be sad and lament, for Your Grace has among your clerics and seculars more than forty-five martyrs. ${ }^{50}$

The Jesuit exiles from Ethiopia spent the last years of their lives in Goa articulating a coherent narrative of their collective suffering and failure. One important contribution to this effort is Manuel de Almeida's aforementioned book, History of Ethiopia, which he indeed completed in Goa in $1643 .{ }^{51}$ The final chapter of his last volume pays homage to the Jesuits who died in exile during this period. ${ }^{52}$ In this section, he gives an account of the exemplary lives of those who returned with him to Goa. De Almeida's text transforms the Society's mission in Ethiopia into a tale of martyrdom, depicting the stoic manner in which Jesuits faced the vicissitudes, frustrations, and attrition of apostolic work. A case in point is de Almeida's veneration of António Fernandes:

He [António Fernandes] was wont to say, speaking of the long and arduous roads he obediently traveled to Emperor Seltan Segued [i.e., Susənyos] when he attempted to go by land to the coast of Melinde and from there to India. [.. .] He imagined himself in the midst of an immense and uncultured barbarism, as an ant in a great field through which countless number of people tread, and the little ant in the midst of it all, endlessly carrying its load of grains of wheat or corn without stopping or getting distracted by the traffic, unafraid of getting stepped on, nor trying to get out of the way of the traders, but minding only its own. I believe the Father had had this thought not only on that occasion, but all his life, because whatever happened, whatever he saw, in prosperous or adverse events, sad or happy news, we never saw him change, stop his obligations, or think of putting off the spiritual exercises or the holy works and duties he had in hand..$^{53}$

Almeida also referred to the virtues of Fernandes:

Suffice it as proof how Father Fernandes subjected his passions to reason; it is well known that for many years no choleric word was heard from his

50 Beccari, Rerum Aethiopicarum scriptores, 13:264.

$5^{1} \quad$ Hervé Pennec discusses the important place of writing history in the missionary enterprise. He focuses specifically on the cases of Fathers Manuel de Almeida and Pedro Páez. See Hervé Pennec, Des Jésuites au Royaume du Prêtre Jean (Éthiopie) (Paris: Centre Cultural Calouste Gulbenkian, 2003), 241-306. See also Kleiner, “Almeida, Manoel de," 207-9.

52 Beccari, Rerum Aethiopicarum scriptores, 7:461. 
mouth even against those who offended him. Whenever he referred to himself, he did so referring to God, resigning himself to His divine will and giving Him thanks in both, prosperous or adverse events. ${ }^{54}$

Diogo de Mattos (1586-1642) also merited de Almeida's praise:

In many journeys, he endured grievous hunger and cold with such joyous countenance and good spirits that he gave it to all, captains and soldiers, even in the midst of battles and greater perils [...]. Father Diogo Mattos was so uncomplaining and patient that in times when men used against him injurious words, he responded as David, Obmitui et humiliatus sum et silui a bonis [I was dumb, and was humbled, and kept silence even from good things]. ${ }^{55}$ Still when others piqued and annoyed him, he pretended not to understand and responded by doing them as much good as he could, heeding the advice of Saint Paul, vince in bono malum [overcome evil with good].${ }^{56} \mathrm{He}$ was deeply patient, and there was not a day in which he did not discipline himself with great rigor. ${ }^{57}$

That said, Mattos's disposition was less tranquil than this passage lets on. Elsewhere, Almeida informs us that he could be impatient and violent; on the island of Daga, he destroyed altars, drapes, and books in churches of the "heretics." ${ }^{58}$ Nonetheless, Almeida searched for a positive interpretation of his behavior. Mattos was a monster at times, writes Almeida, and yet, he was patient, long-suffering, and disciplined. ${ }^{59}$

Almeida elaborates further on the illnesses and corporal suffering endured by Antonio Bruno of Sicily (1590-1640), who entered Ethiopia with Mattos in 1619. He returned in 1634 with the other priests who had been banished and handed over to the Turks. According to Almeida,

He suffered great hardships on the road due to a skin rash ailment on most of his body which caused him great torment almost as long as his life lasted. In Goa, he had maladies with prolonged agues. He developed an internal abscess that plagued him grievously $[\ldots]$ so that for two or

\footnotetext{
54 Beccari, Rerum Aethiopicarum scriptores, 7:475.

55 "I was dumb, and was humbled, and kept silence from good things" (Psalms 38:3).

56 "Do not be overcome by evil but overcome evil with good" (Romans 12:21).

57 Beccari, Rerum Aethiopicarum scriptores, 7:471.

$5^{8}$ Beccari, Rerum Aethiopicarum scriptores, 7:440-41.

59 Beccari, Rerum Aethiopicarum scriptores, 7:471.
} 
three months he continuously spewed blood, coughing with great force and suffering great pain until he died. He suffered these grievous ailments with admirable patience and great resignation to the divine will, since he was most mortified and penitent all his life, sleeping on the ground in Ethiopia with only a stone for headrest. He also suffered great affliction from scruples that lasted many years, causing him great discomfort in the exercise of the divine offices and sacraments. ${ }^{60}$

These personal examples are embedded within the larger narrative of the failure of the mission and the attempt to give meaning to such sacrifice. After the successive failed attempts to enter Ethiopia, Almeida points out: "more than fruit, it has been expenses and toil that have been harvested." "Such glorious mission," writes the priest,

though having yielded thorns these years, in others bore copious fruit of select wheat, much of which was treasured in the coffers of heaven, with the glory of God and by virtue of the Society. And even if its fruit were nothing more than the purple roses of so many martyrs born amidst thorns, their fragrance and subtle scent have filled not only the hills and shrubs of Ethiopia, but the entire militant Church, where its victories are chronicled and celebrated. Its triumph of new palms, to be reaped from the land that for so many centuries yielded nothing of the kind, is to be held in high esteem. ${ }^{61}$

Jesuit martyrdom clearly served to create a sense of cohesion within the order's ranks. No less important, though, was how it countered the accusations leveled against the order by its detractors. Let us take, for instance, a letter penned in 1640 by the Augustinian Manuel de Asunção that he sent to the Sacra Congregatio de Propaganda Fide. In this missive, Asunção rebukes the Jesuits for abandoning the apostolic spirit and voluntary poverty, which he believed was an attractive form of sanctity, in the lands they sought to convert. Asunção argued that the success of evangelization depended on the degree to which ministries expressed the virtues of voluntary continence and poverty. In the Augustine friar's opinion, the Jesuits in Ethiopia played a flawed role as apostles of the Gospel, desiring worldly possessions and property. As evidence, Asunção described the local cultures of the East (which, for him, included

6o Beccari, Rerum Aethiopicarum scriptores, 7:470.

61 Beccari, Rerum Aethiopicarum scriptores, 7:461. 
Ethiopia) as worshiping and embracing the virtues of humility, continence, and poverty. ${ }^{62}$

Such accusations should be considered within the framework of the relations between the different Catholic orders. In this context, the CapuchinJesuit rivalry over the Ethiopian project was highly significant. After the expulsion of the Society, the Sacra Congregatio de Propaganda Fide's interest in Ethiopia grew, as they tasked Capuchin monks with reviving Catholicism along the Horn of Africa. ${ }^{63}$ The rumors spread by the Jesuits' rivals triggered this new phase of the mission. ${ }^{64}$

Besides the goal of legitimization, the narrative at hand foregrounds the proper way to contend with suffering. In the Ignatian discourse, patience seems to be a tool for coping with indignities. Especially during the so-called apostolic difficulties, "Christ, the Lord benefits considerably more from the travails of those who are sent to evangelize a city, for the difficulties and obstacles the enemy raises are much greater. That is to say, he always tries to impede the service of the Lord."65 Patience of its protagonists stands out as well. In the rich Castilian language of Sebastián de Covarrubias Orozco, which call to mind the semantics of the Golden Age, patience entails "tolerance and sufferance." 66 Patience is humility verified by daily vicissitudes, Ignatius dixit. The privileged occasion to experience patience is in sickness, ${ }^{67}$ and in general, situations that involve contempt or a delay in achieving a set objective. ${ }^{68}$ Ignatius continued,

62 Beccari, Rerum Aethiopicarum scriptores, 13:186-87.

63 See Metodio Carobbio da Nembro, "Martirio ed espulsione in Etiopia," in Sacrae Congregationis Propaganda Fide memoria rerum: 350 anni a servizio delle Missioni, 1622-1972, ed. Josef Metzler, 3 vols. (Rome: Herder, 1971), 1/1:624-49.

64 Merid Wolde Aregay, "The Legacy of the Jesuit Missionaries in Ethiopia from 1555 to 1632," in The Missionary Factor in Ethiopia, ed. Getatchew Haile et al. (Frankfurt am Main: Peter Lang, 1988), 56. The Jesuit Manuel de Almeida, who was expelled from Ethiopia along with Patriarch Mendes, points out that this new decision was taken by the Propaganda as a result of "insincerity and untruthfulness" of the information that circulated on the reasons for the expulsion. Beccari, Rerum Aethiopicarum scriptores, 7:403. Afonso Mendes, for his part, devotes a chapter of his monumental work Expeditio Aethiopica to exposing the slander aimed at the missionaries in Ethiopia and Goa. Beccari, Rerum Aethiopicarum scriptores, 9:253-58.

65 Santiago Arzubialde, "'Dolerse de' y 'Padecer por' en la mente de S. Ignacio: Reflexiones en torno al análisis textual," Manresa 65 (1993): 107-38, here 122-23.

66 "Paciencia: virtud que enseña a sufrir los infortunios y tolerar los trabajos en las ocasiones que irritan o conmueven." Sebastián Covarrubias Orozco, Tesoro de la lengua castellana o española, ed. Felipe C. R. Maldonado and rev. Manuel Camarero, 3 vols. (Madrid: Castalia, 1994), 3:70.

67 Constitutions of the Society of Jesus, 89, 272, 304.

68 Monumenta Ignatiana, 12 vols. (Madrid: Typis Gabrielis Lopez del Horno, 1903), 1:143; 4:59; 6:301. 
"He who is in grief, let him strive for patience, which is contrary to the vexations on him, and let him know that he will be swiftly consoled, after having given due diligence against such grief." 69

Almeida and Mendes strove to imbue with meaning the history of missionaries in Ethiopia and, more broadly, the Catholic enterprise there. Mendes's catalog of martyrdom, the construction of a new narrative emphasizing his own sacrifice, as well as the manner in which Almeida concludes his voluminous work History of Ethiopia with a biographical review of martyred Jesuits, demonstrate the vigorous efforts of Jesuit leaders to frame the failure and grief experienced by their community in Ethiopia. Here, these biographies are transformed into episodes in the history of the collective with which the men are identified: the Society of Jesus, the universal church, and Christian martyrs. The present suffering of the Jesuits reenacts the past suffering of the church's founders. Individual experience thus acquires a meaning in an all-embracing context of significance, which, by virtue of its own nature, manages to transcend it. In this way, "the pain becomes more tolerable, the terror less overwhelming, as the sheltering canopy of the nomos extends to cover even those experiences that may reduce the individual to howling animality."70

\section{Avoiding Excessive Emotionalism}

As per the directive of Francis Xavier (1506-52), Ines Županov observes, missionaries in Asia were expected to follow orders, behave in a disciplined manner, and hold their emotions in check. ${ }^{71}$ The stories under review present the order's emissaries confronting difficulties and disillusionment with the quintessential Ignatian traits of patience and forbearance. ${ }^{72}$ In these emblematic tales, the Jesuits face grief with fortitude and, above all, equanimity, modesty, and austerity. Tears are shed only for the grief of others, for those good Catholics who by the expulsion were cut off from their guides and protectors. For instance, when recounting the farewell ceremony that took place when the patriarch was ordered to abandon his residence and leave the kingdom, Almeida writes: "Having ended the music among the tears and cries of the

69 Spiritual Exercises, 321. See also Germán Arana, "Paciencia," in Diccionario de espiritualidad ignaciana, 2:1391.

70 Peter L. Berger, The Sacred Canopy: Elements of a Sociological Theory of Religion (New York: Anchor Books, 1990), 55 .

71 Županov, Missionary Tropics, 164. See also Felix Zubillaga, ed., Cartas y escritos de San Francisco Javier (Madrid: Biblioteca de Autores Cristianos, 1979), 357-63.

72 Arzubialde, "Dolerse y padecer," 125. 
many poor who bemoaned their helplessness, we all set off on our way."73 Moreover, Almeida tells how upon hearing Mendes's words,

All that were in attendance could not hold back the tears. Rising to his feet, [Mendes] told them: "Do not weep, but if thou must, let it be for them and thy kingdom, against which the angel of God has unsheathed his sword. Yet, sing and help us sing, for today we commence to be disciples of Christ and the time is at hand when he says: Beati estis cum maledixerunt vobis, et persecutivos fuerint, et dixerint omne malum adversum vos mentientes, propter me: gaudete, et exsultate, quoniam merces vestra copiosa est in caelis (MATTHEW 5:11). ${ }^{74}$

Upon bidding farewell to Francisco Carvalho and Francisco Marques, the people of Agäw wept; ${ }^{75}$ and the same can be said for the Catholics of Nebesse when they accompanied the martyr Bruno Bruni (1590-1640) on his final path. ${ }^{76}$

Social psychologists tell us that the group, like the individual, requires a sense of temporal connection. Mendes's decision to pen his martyrology during the final years of his life reflects such a wish, as he sought to foster cohesion in space and continuity over time for a group confronting rupture, disillusionment, and decline. "If a group feels history-less," writes Heinz Kohut, "it lacks an important aspect of a live, vital group self." ${ }^{\prime 7}$ There is no group self if there is nothing to hold onto. ${ }^{78}$

73 Beccari, Rerum Aethiopicarum scriptores, 7:236.

74 Beccari, Rerum Aethiopicarum scriptores, 7:235.

75 The Agäw peoples are the principal original inhabitants of northern and central Ethiopia, see Frederick C. Gamst, "Agäw Ethnography," in Encyclopaedia Aethiopica, 1:142-43; James Quirin, "Agäw Mədər," in Encyclopaedia Aethiopica, 1:143-44. The Jesuits developed important strategies to convert the Agäw population to Catholicism. See Leonardo Cohen, The Missionary Strategies of the Jesuits in Ethiopia (1555-1632) (Wiesbaden: Harrassowitz Verlag, 2009), 37-42.

76 Beccari, Rerum Aethiopicarum scriptores, 7:188.

77 Heinz Kohut, Self-Psychology and the Humanities: Reflections on a New Psychoanalytic Approach, ed. Charles B. Strozier (New York: W. W. Norton, 1985), 236.

78 Kohut, Self-Psychology, 237. Julia Kristeva also points out the relationship between a sense of self, the experience of trauma and suffering, and creative symbolic expression in both art and religion. Her main work, Black Sun, focusses on traumatic, disruptive, and disintegrating dimensions of psychological experience, and how symbolic and aesthetic creation is a response to suffering, melancholia, and loss of meaning. See Julia Kristeva, Black Sun: Depression and Melancholia, trans. Leon S. Roudiez (New York: Columbia University Press, 1989); see also, James Dicenso, "New Approaches to Psychoanalysis and Religion: Julia Kristeva's Black Sun," Studies in Religion/ Sciences religieuses 24 (1995): 279-95. 
While confronting the failure to spiritually conquer Ethiopia, the aged Mendes strove to reconcile the Jesuits' initial ambitions with their ultimate frustrations. The redaction of the martyrdom process and the formulation of a text created a space in which a harmonious relationship between past and present could be fashioned. In 1654, from his exile in Goa, the Catholic patriarch compiled a "catalog of Ethiopian martyrs under the rule of Emperor Fasilädäs." Drawing on information from Bernardo Nogueira, Mendes commemorates the lives of virtuous Catholics who died in the name of their faith. ${ }^{79}$ In his letter from January 15, 1654, Mendes tells of having confessed and received the sacred viaticum as he was bedridden by illness. He convalesced thanks to the intervention of the holy martyrs. As a result, the father would "have time before departing from this vessel, to end them all." ${ }^{80}$ In Mendes's estimation, then, the martyrs not only bore witness to the gospel and followers of Christ, but are heavenly saints that can intercede on their supplicants' behalf.

The histories narrated by Mendes and Almeida display bitterness toward the mendicant orders. ${ }^{81}$ For these Jesuits, writing itself was a form of testimony. Such narratives of martyrdom were designed to provide solace to a grieving community. No less importantly, they offered support to the Catholic missionary world. In so doing, the Society of Jesus was adhering to Ignatian principles, as it confronted grief with discipline, obedience, and patience.

79 Beccari, Rerum Aethiopicarum scriptores, 13:399-407.

8o Beccari, Rerum Aethiopicarum scriptores, 13:390-91.

81 Beccari, Rerum Aethiopicarum scriptores, 13:391, 394-95. 